\title{
Comparison of different sample preparation methods for platinum determination in cultured cells by graphite furnace atomic absorption spectrometry
}

\author{
Man Xiao $^{1}{ }^{\text {, }}$ Zaiju Huang ${ }^{1}$, Jing Cai ${ }^{1}$, Jinghui Jia ${ }^{2}$, Yuzeng Zhang ${ }^{3}$, Weihong Dong ${ }^{1}$, Zehua Wang ${ }^{\text {Corresp. }}{ }^{1}$ \\ 1 Department of Obstetrics and Gynecology, Union Hospital, Tongji Medical College, Huazhong University of Science and Technology, Wuhan, China \\ 2 Department of Obstetrics and Gynecology, Air Force General Hospital, PLA, Beijing, China \\ 3 Department of Occupational and Environmental Health, School of Public Health, Tongji Medical College, Huazhong University of Science and Technology, \\ Wuhan, China \\ Corresponding Author: Zehua Wang \\ Email address: zehuawang@163.net
}

Background. Platinum-based agents are widely used in chemotherapy against solid tumors and insufficient intracellular drug accumulation is one of the leading causes of platinum resistance which is associated with poor survival of tumor patients. Thus, the detection of intracellular platinum is pivotal for studies aiming to overcome platinum resistance. In the present study, we aimed to establish a reliable graphite furnace atomic absorption spectrometry (GFAAS)-based assay to quantify the intracellular platinum content for cultured cells.

Methods. Several most commonly applied cell preparation methods, including $0.2 \% \mathrm{HNO}_{3}, 0.2 \%$ Triton X-100, concentrated nitric acid, RIPA combined with concentrated nitric acid and hydroxide, followed by GFAAS for platinum detection were compared in ovarian, cervical and liver cancer cell lines to obtain the optimal one, and parameters regarding linearity, accuracy, precision and sensitivity were evaluated. Influence of other metals on platinum detection and the storage conditions of samples were also determined.

Results. The treatment of cells with $0.2 \% \mathrm{HNO}_{3}$ was superior to other approaches with fewer platinum loss and better repeatability. The recovery rate and precision of this method were $97.3 \%-103.0 \%$ and $1.4 \%-3.8 \%$, respectively. The average recoveries in the presence of other metals were $95.1 \%-103.1 \%$. The detectionlimit was $13.23 \mathrm{ug} / \mathrm{L}$. The recovery rate of platinum remained acceptable even in cell samples stored in $-20^{\circ} \mathrm{C}$ or $-80^{\circ} \mathrm{C}$ for two months.

Discussion. After comparison, we found that $0.2 \% \mathrm{HNO}_{3}$ was optimal for intracellular platinum quantification based on GFAAS, which presented values compatible with that of inductively-coupled plasma mass-spectrometry (ICP-MS), and this is partially attributed to the simplicity of this method. Moreover, the assay was proved to be accurate, sensitive, cost-effective and suitable for the research of platinum-based antitumor therapy. 
1 Comparison of different sample preparation methods for platinum

2 determination in cultured cells by graphite furnace atomic absorption

4 Man Xiao ${ }^{1 *}$, Zaiju Huang ${ }^{1 *}$, Jing Cai ${ }^{1}$, Jinghui Jia ${ }^{2}$, Yuzeng Zhang ${ }^{3}$, Weihong Dong ${ }^{1}$, Zehua

5 Wang 1

$6{ }^{1}$ Department of Obstetrics and Gynecology, Union Hospital, Tongji Medical College, Huazhong

7 University of Science and Technology, Wuhan 430022, Hubei Province, P. R. China.

$8{ }^{2}$ Department of Obstetrics and Gynecology, Air Force General Hospital, PLA, Beijing 100142,

9 P.R. China

$10{ }^{3}$ Department of Occupational and Environmental Health, School of Public Health, Tongji Medical

11 College, Huazhong University of Science and Technology, Wuhan 430022, Hubei Province, PR

12 China.

13 * These authors contributed equally to this work.

14 Corresponding author

15 Zehua Wang,

16 Department of Obstetrics and Gynecology, Union Hospital, Tongji Medical College, Huazhong

17 University of Science and Technology, No. 1277 Jiefang Avenue, Wuhan, 430022, China. 


\section{Abstract}

23 Background. Platinum-based agents are widely used in chemotherapy against solid tumors and insufficient intracellular drug accumulation is one of the leading causes of platinum resistance which is associated with poor survival of tumor patients. Thus, the detection of intracellular platinum is pivotal for studies aiming to overcome platinum resistance. In the present study, we aimed to establish a reliable graphite furnace atomic absorption spectrometry (GFAAS)-based assay to quantify the intracellular platinum content for cultured cells.

Methods. Several most commonly applied cell preparation methods, including $0.2 \% \mathrm{HNO}_{3}, 0.2 \%$ Triton X-100, concentrated nitric acid, RIPA combined with concentrated nitric acid and hydroxide, followed by GFAAS for platinum detection were compared in ovarian, cervical and liver cancer cell lines to obtain the optimal one, and parameters regarding linearity, accuracy, precision and sensitivity were evaluated. Influence of other metals on platinum detection and the storage conditions of samples were also determined.

Results. The treatment of cells with $0.2 \% \mathrm{HNO}_{3}$ was superior to other approaches with fewer platinum loss and better repeatability. The recovery rate and precision of this method were $97.3 \%$ $103.0 \%$ and $1.4 \%-3.8 \%$, respectively. The average recoveries in the presence of other metals were $95.1 \%-103.1 \%$. The detection limit was $13.23 \mathrm{ug} / \mathrm{L}$. The recovery rate of platinum remained acceptable even in cell samples stored in $-20^{\circ} \mathrm{C}$ or $-80^{\circ} \mathrm{C}$ for two months.

Discussion. After comparison, we found that $0.2 \% \mathrm{HNO}_{3}$ was optimal for intracellular platinum quantification based on GFAAS, which presented values compatible with that of inductivelycoupled plasma mass-spectrometry (ICP-MS), and this is partially attributed to the simplicity of 
43 this method. Moreover, the assay was proved to be accurate, sensitive, cost-effective and suitable

44 for the research of platinum-based antitumor therapy.

\section{Introduction}

46 Platinum complexes are first-line chemotherapy agents for treatment of numerous solid

47 malignancies, including tumors from ovary, testes, bladder, head and neck, cervix and lung

48 (Lebwohl \& Canetta 1998; Rosenberg 1985). Nevertheless, the therapeutic outcome of platinum

49 complexes is largely impaired by drug resistance. The mechanisms of platinum-resistance mainly

50 include reduced drug accumulation, elevated levels of glutathione and metallothionein, enhanced

51 DNA repair capacity, and inhibition of apoptosis (Holohan et al. 2013; Zisowsky et al. 2007). It

52 is therefore of great interest to identify a reliable assay offering accurate assessment of

53 intracellular platinum in tumor cells.

54 With regard to the techniques for metals determination in a variety of sample types, atomic

55 absorption spectrometry (AAS), high performance liquid chromatography (HPLC) and

56 inductively coupled plasma-mass spectrometry (ICP-MS) are frequently employed in most

57 research teams. AAS encompasses the technique of flame atomic absorption spectrometry

58 (FAAS) and flameless atomic absorption spectrometry; the latter mainly includes graphite

59 furnace atomic absorption spectrometry (GFAAS). With higher tolerance to inorganic and organic matrices and higher sensitivity compared with FAAS, GFAAS has been enjoying a high reputation as a mature and sensitive technique used in routine determination of metal contents

62 (Chappuy et al. 2010; Dessuy et al. 2011; Lewen 2011). With spectrophotometric, fluorescence, electrochemical and quenched phosphorescence detection methods, HPLC is characterized with 
64 high specificity and selectivity (Boiteau et al. 2013; Khuhawar \& Arain 2005; Santa 2013). ICP-

65 MS has captured increasing attention in recent years with substantially lower detection limits and 66 advantages for multi-element analyses over GFAAS (Fukui et al. 2011; Ikeda et al. 2011; Lewen

67 2011). Nevertheless, the time consuming operation (e.g. liquid-liquid back extractions) of HPLC

Early in 1980s, Smeyers-Verbeke et al. developed the method for platinum determination in biological fluid by GFAAS, in which samples (blood, plasma, serum and urine) were lyophilized and wet ashed to destruct the organic material (Smeyers-Verbeke et al. 1981). After that, Cabrera-Vigue et al. established a method by microwave acid digestion to determine platinum in wine using standard addition method by GFAAS. They found that platinum levels in most wines were $<10 \mathrm{ug} / \mathrm{L}$ (Cabrera-Vique et al. 1997). Recently, GFAAS was used for preparation and characterization of magnetic nanoparticles harboring platinum in mine samples. To achieve the best analytical performance, the $\mathrm{pH}$ value, loading time and flow rate of sample, concentration and flow rate of eluent were optimized by Ye et al (Ye et al. 2014). Nevertheless, most of the existing methodological researches on the usage of GFAAS are restricted to biological and 
85

86

87

industrial materials. The literature regarding the determination of platinum in cultured cell lines by GFAAS is quite limited, though the tumor cells cultured in vitro are widely employed in studies investigating drug resistance mechanisms. To address this issue, we aimed to identify a reliable GFAAS-based assay to determine the intracellular platinum content especially for cultured cells.

Sample preparation, for both tissues and cultured cells, counts a lot for an accurate measurement of platinum concentration. Without connective fibers, the time-consuming, hazardous lyophilization and wet ashing for tissue digestion are unnecessary. Several sample preparation procedures for cultured cells such as $0.2 \%$ and $0.6 \%$ nitric acid $\left(\mathrm{HNO}_{3}\right)$ (Burger et al. 2010; Davis et al. 2012), 0.2\% and 1\% Triton X-100 (Burger et al. 1997; Yunos et al. 2011), concentrated nitric acid (Buss et al. 2011; Kalayda et al. 2012; Rotte et al. 2010; Zisowsky et al. 2007) and hydroxide (Noordhuis et al. 2008) have been used for platinum analysis using flameless AAS (graphite tube were used) and GFAAS. In addition, another cell processing procedure (a lysis buffer + concentrated nitric acid) followed by HPLC on line with ICP-MS was also used for platinum determination (Federici et al. 2014). Nevertheless, the lack of a systematic methodological quality assessment of these assays made it blind for researchers to select an appropriate method to measure platinum concentration in cells. We compared therefore the most widely used sample processing procedures to obtain an optimal GFAAS-based assay with simplicity, veracity, and sensitivity for determination of platinum concentration in cultured cells. . 
107 Materials \& Methods

108 Reagents

109 Analytical grade reagents were used exclusively. Cisplatin and Triton X-100 were respectively

110 purchased from Qilu pharmaceutical company (China) and Amresco (America). Concentrated

111 nitric acid (10014518), standard solutions of Ca (40272064), Mg (53203671), Zn (53205273),

$112 \mathrm{Cu}$ (53205181), K (40243861), Na (40262163), Mn (53204676) and Fe (40940260) were

113 obtained from Sinopharm Chemical Reagent Co., Ltd, China. Different concentrations of nitric

114 acid and Triton X-100 and a standard solution of $300 \mathrm{ug} / \mathrm{L}$ platinum were prepared with

115 deionized water, which was obtained from the SNW ultra-pure water system with a resistivity of

$11618.2 \mathrm{M}$ (Heal Force, China).

\section{Cell lines and cell culture}

119 Human epithelial ovarian cancer A2780 (ECACC) and $\mathrm{CAOV}_{3}$ (ATCC) cells, cervical cancer

120 HeLa (ATCC) cells and liver carcinoma Hep $\mathrm{G}_{2}$ (ATCC) cells were cultured in RPMI-1640

121 medium (Gibco, USA) supplemented with 10\% fetal bovine serum (Gibco, USA) in a humidified

122 atmosphere containing $5 \% \mathrm{CO}_{2}$ at $37^{\circ} \mathrm{C}$. Cisplatin-resistant variant of $\mathrm{A} 2780$ (A2780/CDDP)

123 was generated by exposure to increasing concentration of cisplatin. After being incubated with

124 cisplatin, cells were washed 3 times with ice-cold phosphate buffered saline (PBS) to rinse the

125 dead cells and remaining drug. Then cells were harvested with trypsin and washed twice with

126 ice-cold PBS. Ultimately, cell suspensions were divided into equal aliquots and kept frozen (- 
$12720^{\circ} \mathrm{C}$ or $-80^{\circ} \mathrm{C}$ ) after the supernatants were discarded. One of the aliquots was removed for

128 protein content measurement via Bradford method (Beyotime Biotechnology, China), the others

129 for platinum determination. The intracellular platinum levels were expressed as ng of Pt per

130 aliquot or ng of Pt per mg of protein. The present study was approved by the ethical committee

131 of Union Hospital, Tongji Medical College, Huazhong University of Science and Technology,

132 China (Approval number: 2014073).

\section{Sample preparation and operating condition of instrument}

135 All cell aliquots were kept frozen $\left(-20^{\circ} \mathrm{C}\right)$ until the day for GFAAS analysis. Immediately after 136 thawing, cell pellets were respectively processed according to following procedures: (1) $0.2 \%$ $137 \mathrm{HNO}_{3}$ at room temperature (Burger et al. 2010), 2 0.2\% Triton X-100 on ice (Burger et al. 138 1997), (3) concentrated nitric acid at $60^{\circ} \mathrm{C}$ for 20 minutes (Rotte et al. 2010; Zisowsky et al. 139 2007), (4) concentrated nitric acid at $80^{\circ} \mathrm{C}$ for 1 hour (Buss et al. 2011; Kalayda et al. 2012), (5) RIPA (Beyotime Biotechnology, China) complemented with concentrated nitric acid at $60^{\circ} \mathrm{C}$ for 2 hours (Federici et al. 2014) and (6) $2 \mathrm{M} \mathrm{NaOH}$ at $55^{\circ} \mathrm{C}$ overnight subsequently neutralization with $1 \mathrm{M} \mathrm{HCl}$ (Noordhuis et al. 2008).

144 The platinum lamp used in this work was operated at a current of $10 \mathrm{~mA}$. Analysis was 145 performed using an atomic absorption spectrometer (SpectrAA-240 FS, VARIAN, USA) to 146 monitor the platinum absorbance at $265.9 \mathrm{~nm}$ corrected by deuterium background signals, with a 147 slit width of $0.2 \mathrm{~nm}$. Argon was used as the inert gas in all analyses. Standard solutions and 
148 samples were injected in duplicate on the platform inside the graphite tube by the auto-sampler

149 needle. The furnace was programmed to execute a 75 -s drying phase at $85-120^{\circ} \mathrm{C}$, followed by 8 -

150 s of ashing at $1000^{\circ} \mathrm{C}$, then a $4.9-\mathrm{s}$ atomization at $2700^{\circ} \mathrm{C}$.

151

152 With $300 \mathrm{ug} / \mathrm{L}$ platinum solution as standard mother liquor, the blank and preparation solutions

153 were the corresponding cell processing liquid mentioned above. The platinum standard addition

154 solutions $(60 \mathrm{ug} / \mathrm{L}, 120 \mathrm{ug} / \mathrm{L}$, and $240 \mathrm{ug} / \mathrm{L})$ used in this study were automatically generated by

155 the instrument based on the mother liquor. Matrix effect was corrected on the pattern of standard

156 addition. Calibration curves of different sample preparation methods were drawn according to

157 the absorbance of standard addition solutions and correlation coefficients of all curves were

158 calculated .

159

160 Accuracy and precision

161 Accuracy is defined as the agreement between the observed value and the true value and

expressed as recovery rate in a percentage form. For the assessment of accuracy, high (125 ug/L),

medium (85 ug/L) and low (45 ug/L) concentration standard solutions were added to

corresponding high (110.9 ug/L, Hep G2), medium (96.5 ug/L, A2780) and low (48.6 ug/L,

A2780) concentration samples (Shah et al. 1991; Westgard 1981). Then, the three mixtures of

standard solutions and samples were analyzed for six times. The average recovery rate was

calculated as following: (average value of sextuple tests - sample concentration)/ concentration

of standard solution. Generally, 90 to $100 \%$ recovery was considered acceptable (Westgard 
169

170

171

172

173

174

175

176

177

178

179

180

181

182

183

184

185

186

187

188

189

1981).

Precision, defined as the agreement of replicate measurements of the same sample and calculated as the relative standard deviation (RSD) (Lewen 2011; Shah et al. 1991; Vouillamoz-Lorenz et al. 2001), was evaluated by performing six replicate injections at four different concentration levels of A2780 cells (the average concentration of Low level: $44.6 \mathrm{ug} / \mathrm{L}$, Medium-low: $82.9 \mathrm{ug} / \mathrm{L}$, Medium-high: 119.5 ug/L, High: 190.2 ug/L) (Tiwari \& Tiwari 2010). An analytical method was considered precise when the RSD was less than $15 \%$ except at the detection limit where $20 \%$ RSD was accepted (Shah et al. 1991; Tiwari \& Tiwari 2010).

\section{Sensitivity}

The sensitivity of an assay was evaluated by its detection limit, which is numerically equal to 3 times the standard deviation of at least 10 distinct measurements of blank samples (VouillamozLorenz et al. 2001).

\section{Interference}

Interference is defined as the effect of a component on the accuracy of the measurement of another component, which may result in high values (enhancement) or low values (inhibition) (Westgard 1981). In this study, the interference from the metals coexisting in cells to platinum measurement was evaluated. Based on the content of metals contained in cells, a final concentration of $90.9 \mathrm{mg} / \mathrm{L} \mathrm{Ca}^{2+}$ and $\mathrm{Mg}^{2+}$ were added to $95.3 \mathrm{ug} / \mathrm{L}$ Hep $\mathrm{G} 2$ cell samples, 12.2 $\mathrm{mg} / \mathrm{L} \mathrm{Zn}^{2+}, \mathrm{K}^{+}, \mathrm{Na}^{+}$and $1.2 \mathrm{mg} / \mathrm{L} \mathrm{Cu}^{2+}$ and $\mathrm{Mn}^{2+}$ to $102.2 \mathrm{ug} / \mathrm{L}$ Hep $\mathrm{G} 2$ cell samples and 1.1 
190

191

192

193

194

195

196

197

198

199

200

201

202

203

204

205

206

207

208

209

210

$\mathrm{mg} / \mathrm{L} \mathrm{Fe}^{2+}$ to a $75 \mathrm{ug} / \mathrm{L}$ Hep G2 cell sample. The platinum concentration in each mixture was measured for six times and the average value was used for calculation of the recovery rate, which was determined by the ratio of the platinum concentration in the sample with metal addition to that in the corresponding parent samples. In general, an average recovery rate of $90 \%$ to $110 \%$ was considered to be acceptable.

\section{Stability}

To evaluate the long-term storage stability, A2780, HeLa, and Hep G2 cells were stored at $-20^{\circ} \mathrm{C}$ and $-80^{\circ} \mathrm{C}$ for $7,14,21,35$ and 60 days before treatment with $0.2 \% \mathrm{HNO}_{3}$ and GFAAS assays, and the platinum contents in these samples were compared with freshly harvested cell.

To assess the stability of platinum concentration during sample processing, the processed cell samples were stored in room temperature without sealing for three hours followed by GFAAS analysis. In addition, the platinum contents of samples prepared and stored in sealed tubes were detected over the next 24 and 48 hours. Stability was calculated by comparing the platinum concentrations assessed at each time point to the corresponding freshly prepared samples. The results within $85 \%-115 \%$ was considered to be acceptable (Kloft et al. 1999).

\section{Method application}

A2780 and $\mathrm{CAOV}_{3}$ cells were treated with $20 \mathrm{uM}$ cisplatin for 12, 24, 36, 48, and 72 hours. The intracellular platinum contents were analyzed and platinum concentration-time curves were drawn. In addition, the intracellular platinum accumulation in A2780 was compared with that in 
211 its cisplatin-resistant subline A2780/CDDP after incubation with $20 \mathrm{uM}$ cisplatin for 24 hours.

212 Each assay was performed in triplicate.

213

214 Statistical analysis

215 Data were expressed as mean \pm standard deviation. Differences between groups were analyzed

216 using student's t-test. All tests were two-tailed and P-values of $<0.05$ were considered

217 statistically significant.

219 Results

220 Comparison of different sample preparation methods

221 To determine the intracellular platinum concentration, cell pellets were processed with $0.2 \%$

$222 \mathrm{HNO}_{3}, 0.2 \%$ Triton $\mathrm{X}-100$, concentrated nitric acid and RIPA combined with concentrated nitric

223 acid respectively. Generally, the linearity of the calibration curves was satisfactory with a

224 correlation coefficient higher than 0.99 in all cases (Fig. 1A). The platinum concentrations in

225 samples treated with $0.2 \% \mathrm{HNO}_{3}$ or $0.2 \%$ Triton $\mathrm{X}-100$ were significantly higher than that in

226 samples treated with concentrated nitric acid alone or in combination with RIPA (Fig. 1B),

227 suggesting a significant loss of platinum caused by the processing with concentrated nitric acid.

228 The spectrogram of samples processed using $\mathrm{NaOH}$ combined with $\mathrm{HCl}$ was undulate and lacked

229 a wave crest at $265.9 \mathrm{~nm}$. Hence, this method was excluded.

231 As shown in Fig. 1B, the difference of platinum contents between samples processed with $0.2 \%$ 
$232 \mathrm{HNO}_{3}$ and $0.2 \%$ Triton $\mathrm{X}-100$ was not statistically significant. Nevertheless, the treatment with

$2330.2 \% \mathrm{HNO}_{3}$ was superior to $0.2 \%$ Triton $\mathrm{X}-100$ in light of repeatability indicated by a RSD of

$2343.6 \%$ versus $24.7 \%$. In addition, the impact of nitric acid concentrations ranging from $0.05 \%$ to $5 \%$

235 on the platinum determination was investigated. As shown in Fig. 1C, there was no significant

236 difference in the platinum concentrations between groups. However, samples prepared with $0.2 \%$

$237 \mathrm{HNO}_{3}$ gave the littlest RSD among the different concentrations of nitric acid, suggesting a better

238 ability of $0.2 \% \mathrm{HNO}_{3}$ to eliminate matrix interference. Thus, the $0.2 \% \mathrm{HNO}_{3}$ treatment was used

239 to prepare cell samples for subsequent experiments.

241 Accuracy, precision and sensitivity

242 Given that the sample preparation method using $0.2 \% \mathrm{HNO}_{3}$ was characterized with fewer 243 platinum loss and lower RSD in the subsequent GFAAS assays, we thought to further evaluate 244 its accuracy and precision. As shown in Table 1, the average recovery rates of samples at 245 different platinum concentration levels ranged from $97.3 \%$ to $103.0 \%$. The results summarized in 246 Table 2 presented that the RSD were less than 5\% (1.4\%-3.8\%) in all cases and tended to 247 decrease with the increase of platinum content in samples. The detection limit of the assay 248 analyzed was $13.23 \mathrm{ug} / \mathrm{L}$.

\section{Interference}

251 To evaluate the interference of the coexistent metals on this GFAAS-based platinum assay, eight

252 metals including $\mathrm{Ca}, \mathrm{Mg}, \mathrm{Zn}, \mathrm{Cu}, \mathrm{K}, \mathrm{Na}, \mathrm{Mn}$ and $\mathrm{Fe}$ were added in samples containing platinum. 
253 As shown in Table 3, the average recoveries in all cases were between $95.1 \%$ and $103.1 \%$, which

254 indicated that platinum determination was not affected by additional metal.

255

256 Stability

257 As shown in Table 4, there was no significant decrease in intracellular platinum concentration

258 during the 7-60 days storage at $-20^{\circ} \mathrm{C}$ and $-80^{\circ} \mathrm{C}$, which was indicated by the recovery rates

259 between $87.0 \%$ and $113.9 \%$ (Table 4 ).

260

261 Compared with freshly processed samples, the results in Table 5 revealed no significant 262 alteration in platinum content of samples processed and stored without sealing for three hour, 263 excluding the effects of solvent evaporation during measurement on the test results, which can 264 lead to an increase in platinum concentration. Moreover, the platinum concentrations in processed samples that were stored in sealed tubes over a period of 48 hours were also found to be acceptable, with recovery rates between $92.8 \%$ and $111.2 \%$ (Table 5).

Method application

The proposed method was applied to determine the dynamic change of platinum accumulation in ovarian cancer cells. After incubation with cisplatin, the intracellular platinum concentrations in A2780 and $\mathrm{CAOV}_{3}$ cells increased in a time-dependent manner form 0 hour to 24 and 36 hours respectively and gradually declined afterward (Fig. 2A). The platinum concentrations in A2780 and its resistant variant A2780/CDDP were also measured. Consistent with the literature reported 
274 (Zisowsky et al. 2007), the intracellular platinum accumulation was significantly decreased in the

275 A2780/CDDP cells compared with the A2780 ( $<<0.01$, Fig. 2B).

276

277 Discussion

278 The determination of platinum concentration in cultured cells is useful in studying the 279 mechanisms of platinum-resistance in tumor. Here, we identified a GFAAS-based assay for 280 quantitative platinum detection with high accuracy and precision. We compared different cell treatment procedures and found $0.2 \% \mathrm{HNO}_{3}$ treatment was optimal for subsequent GFAAS platinum analysis with less platinum loss and high repeatability, which might be partially attributed to its simplicity.

High stability of platinum concentrations in samples is a prerequisite for reliable quantification.

Burger (Burger et al. 2010), Buss (Buss et al. 2011) and Zisowsky (Zisowsky et al. 2007) stored samples at $-20^{\circ} \mathrm{C}$, while Takahashi (Takahashi et al. 1993) and Neill (O'Neill et al. 1999) suggested to store samples at $-80^{\circ} \mathrm{C}$ or in liquid nitrogen. In the present study, for the GFAASbased platinum detection, we found that cell samples were allowed to be stored at $-20^{\circ} \mathrm{C}$ or $-80^{\circ} \mathrm{C}$ for at least two months. In addition, we found the platinum concentrations in processed samples could remain stable at room temperature for at least three hours that ensures the comparability of samples with different waiting time before GFAAS analysis.

Internal standard method, standard curve method and standard addition method are often used to 
295

296

297

298

299

300

301

302

303

304

305

306

307

308

309

310

311

312

313

314

315

quantify target metals in a variety of sample types by GFAAS. For the success of an analysis, selecting a proper analytical method is important. The method of internal standardization could provide a compensation of analyte losses during sample preparation, minimize the instrumental variation and correct matrix effect (De Baere et al. 2012). Nevertheless, it is inconvenient to select a proper internal standard in many cases, for that the physical and chemical properties of an internal standard, such as emission wavelength, should be similar to that of the analyte and the internal standard must not be contained in the sample (Zheng et al. 2001). Through the standard curve method, the analytical signal is directly correlated with the concentration of analyte (Honorato et al. 2002), which mainly applies in the situation that the matrices of samples are close to that of the standard solutions. Obviously, standard curve method is not appropriate for platinum detection in cultured cells because of there complicated components. The standard addition method, whereby specific quantities of test samples are spiked with standard solutions, which can tremendously reduce the errors stemming from the physical and chemical differences between the matrices of samples and that of the standard addition solutions (Honorato et al. 2002). Thus, considering the ability to reduce the interference from proteins, nucleic acids and other components contained in cells, the standard addition method was used in the present work. Consistent with this effect, interference experiments revealed that metals at macro $(\mathrm{K}, \mathrm{Na}, \mathrm{Ca}$, $\mathrm{Mg}$ ) and trace levels (Fe, $\mathrm{Cu}, \mathrm{Mn}, \mathrm{Zn})$ had no significant influence on the quantification of platinum.

Wills et al. reported the measurement of cadmium $(\mathrm{Cd})$ levels in cultured retinal pigment 
epithelium cells using GFAAS and the results were compared with that detected by ICP-MS.

317 They found that the two methods gave essentially identical results with $\pm 5 \%$ standard deviation

318 (Wills et al. 2008). Additionally, a study on the compatibility between ICP-MS and GFAAS for

319 Cd detection based on 1,159 blood samples showed a close correlation between the results by the two methods and suggested both methods could be used inter-convertibly when Cd was $>2 \mathrm{ug} / \mathrm{L}$

321 (Fukui et al. 2011). Although the determination limit of ICP-MS is substantially lower than that of GFAAS, both are sufficient for detection of metals such as Cd in human blood (Fukui et al. 2011). All together, these findings confirmed the accuracy of GFAAS.

Reduced drug accumulation in tumor cells has been a well-known mechanism of platinum resistance. Quantifying intracellular platinum content using GFAAS-based assay might promote the research of platinum resistance. Burger et al. proved that organic cation transporter 2, which is involved in the translocation of endogenous and exogenous compounds across epithelial membranes, was also implicated in the cellular uptake of platinum-containing anticancer drugs and contributed to the development of resistance (Burger et al. 2010). In addition, the technique of GFAAS can be applied to evaluate the effect of drug modification and combination therapy.

Enhancing the lipophilicity of oxaliplatin analogues by introducing carrier ligands could promote the early influx rate of drugs and increase intracellular platinum accumulation subsequently (Buss et al. 2011). The use of macromolecular prodrugs (e.g. platinum-albumin complex and platinum-polyethylene glycol complex) exploiting endocytosis as alternative uptake mechanism also has the potential to increase cellular platinum accumulation and overcome multidrug 
337 resistance (Garmann et al. 2008). The combination of cisplatin and two phytochemicals

338 (curcumin and epigallocatechin-3-gallate) could produce synergistic outcomes, i.e., greater

339 cellular accumulation of platinum (Yunos et al. 2011). Recently, GFAAS has also been applied

340 to investigate the newly synthesized platinum-nitroxyl complexes and platinum (IV) texaphyrin

341 conjugate for their potential to circumvent cisplatin resistance (Cetraz et al. 2016; Thiabaud et al.

342 2014), which indicates that quantifying intracellular platinum concentration using the technique

343 of GFAAS might play a role in new drug research and development.

\section{Conclusions}

346 A GFAAS-based assay following sample preparation using $0.2 \%$ nitric acid for determination of 347 platinum accumulation in cultured cells was validated in this work, which was proved to be 348 accurate, sensitive, simple and cost-effective and might improve the research of platinum-based 349 antitumor therapy.

\section{References}

353 Boiteau RM, Fitzsimmons JN, Repeta DJ, and Boyle EA. 2013. Detection of iron ligands in 354 seawater and marine cyanobacteria cultures by high-performance liquid chromatography355 inductively coupled plasma-mass spectrometry. Anal Chem 85:4357-4362. $10.1021 / \mathrm{ac} 3034568$

357 Burger H, Nooter K, Boersma AW, Kortland CJ, and Stoter G. 1997. Lack of correlation 
358

359

360

361

362

363

364

365

366

367

368

369

370

371

372

373

374

375

376

377

378

between cisplatin-induced apoptosis, p53 status and expression of Bcl-2 family proteins in testicular germ cell tumour cell lines. Int J Cancer 73:592-599.

Burger H, Zoumaro-Djayoon A, Boersma AW, Helleman J, Berns EM, Mathijssen RH, Loos WJ, and Wiemer EA. 2010. Differential transport of platinum compounds by the human organic cation transporter hOCT2 (hSLC22A2). Br J Pharmacol 159:898-908. 10.1111/j.14765381.2009.00569.x

Buss I, Garmann D, Galanski M, Weber G, Kalayda GV, Keppler BK, and Jaehde U. 2011. Enhancing lipophilicity as a strategy to overcome resistance against platinum complexes? $J$ Inorg Biochem 105:709-717. 10.1016/j.jinorgbio.2011.02.005

Cabrera-Vique C, Teissedre PL, Cabanis MT, and Cabanis JC. 1997. Determination of platinum in wine by graphite furnace atomic absorption spectrometry. J AOAC Int 80:57-62.

Cetraz M, Sen V, Schoch S, Streule K, Golubev V, Hartwig A, and Koberle B. 2016. Platinum(IV)-nitroxyl complexes as possible candidates to circumvent cisplatin resistance in RT112 bladder cancer cells. Arch Toxicol. 10.1007/s00204-016-1754-3

Chappuy M, Caudron E, Bellanger A, and Pradeau D. 2010. Determination of platinum traces contamination by graphite furnace atomic absorption spectrometry after preconcentration by cloud point extraction. J Hazard Mater 176:207-212. 10.1016/j.jhazmat.2009.11.014

Davis KJ, Carrall JA, Lai B, Aldrich-Wright JR, Ralph SF, and Dillon CT. 2012. Does cytotoxicity of metallointercalators correlate with cellular uptake or DNA affinity? Dalton Trans 41:9417-9426. 10.1039/c2dt30217a

De Baere S, Osselaere A, Devreese M, Vanhaecke L, De Backer P, and Croubels S. 2012. 
379 Development of a liquid-chromatography tandem mass spectrometry and ultra-high380 performance liquid chromatography high-resolution mass spectrometry method for the quantitative determination of zearalenone and its major metabolites in chicken and pig plasma. Anal Chim Acta 756:37-48. 10.1016/j.aca.2012.10.027

383

Dessuy MB, Vale MG, Welz B, Borges AR, Silva MM, and Martelli PB. 2011. Determination of cadmium and lead in beverages after leaching from pewter cups using graphite furnace atomic absorption spectrometry. Talanta 85:681-686. 10.1016/j.talanta.2011.04.050

Federici C, Petrucci F, Caimi S, Cesolini A, Logozzi M, Borghi M, D'Ilio S, Lugini L, Violante N, Azzarito T, Majorani C, Brambilla D, and Fais S. 2014. Exosome release and low pH belong to a framework of resistance of human melanoma cells to cisplatin. PLoS One 9:e88193. 10.1371/journal.pone.0088193

Fukui Y, Ohashi F, Sakuragi S, Moriguchi J, and Ikeda M. 2011. Comparative evaluation of GFAAS and ICP-MS for analyses of cadmium in blood. Ind Health 49:338-343.

Garmann D, Warnecke A, Kalayda GV, Kratz F, and Jaehde U. 2008. Cellular accumulation and cytotoxicity of macromolecular platinum complexes in cisplatin-resistant tumor cells. $J$ Control Release 131:100-106. 10.1016/j.jconrel.2008.07.017

Holohan C, Van Schaeybroeck S, Longley DB, and Johnston PG. 2013. Cancer drug resistance: an evolving paradigm. Nat Rev Cancer 13:714-726. 10.1038/nrc3599

Honorato FA, Honorato RS, Pimentel MF, and Araujo MC. 2002. Analytical curve or standard addition method: how to elect and design--a strategy applied to copper determination in sugarcane spirits using AAS. Analyst 127:1520-1525. 
400 Ikeda M, Ohashi F, Fukui Y, Sakuragi S, and Moriguchi J. 2011. Cadmium, chromium, lead, 401 manganese and nickel concentrations in blood of women in non-polluted areas in Japan, as 402 determined by inductively coupled plasma-sector field-mass spectrometry. Int Arch Occup 403 Environ Health 84:139-150. 10.1007/s00420-010-0542-2

404 Kalayda GV, Wagner CH, and Jaehde U. 2012. Relevance of copper transporter 1 for cisplatin 405 resistance in human ovarian carcinoma cells. $J$ Inorg Biochem 116:1-10. $406 \quad$ 10.1016/j.jinorgbio.2012.07.010

407 Khuhawar MY, and Arain GM. 2005. Liquid chromatographic determination of cis-platin as 408 platinum(II) in pharmaceutical preparation, serum and urine samples of cancer patients. 409

Kloft C, Appelius H, Siegert W, Schunack W, and Jaehde U. 1999. Determination of platinum complexes in clinical samples by a rapid flameless atomic absorption spectrometry assay. Ther Drug Monit 21:631-637.

Lebwohl D, and Canetta R. 1998. Clinical development of platinum complexes in cancer therapy: an historical perspective and an update. Eur J Cancer 34:1522-1534.

Lewen N. 2011. The use of atomic spectroscopy in the pharmaceutical industry for the 416 determination of trace elements in pharmaceuticals. J Pharm Biomed Anal 55:653-661. 10.1016/j.jpba.2010.11.030

418 Noordhuis P, Laan AC, van de Born K, Losekoot N, Kathmann I, and Peters GJ. 2008. 419 Oxaliplatin activity in selected and unselected human ovarian and colorectal cancer cell lines. Biochem Pharmacol 76:53-61. 10.1016/j.bcp.2008.04.007 
421 O'Neill CF, Hunakova L, and Kelland LR. 1999. Cellular pharmacology of cis and trans pairs of 422 platinum complexes in cisplatin-sensitive and -resistant human ovarian carcinoma cells. Chem 423 Biol Interact 123:11-29.

424 Rosenberg B. 1985. Fundamental studies with cisplatin. Cancer 55:2303-12306.

425 Rotte A, Garmann D, Buss I, and Jaehde U. 2010. Effect of extracellular ATP on cisplatin426 induced cytotoxicity in human ovarian carcinoma cells. Chemotherapy 56:1-8. $10.1159 / 000287351$

428

432

Santa T. 2013. Recent advances in analysis of glutathione in biological samples by highperformance liquid chromatography: a brief overview. Drug Discov Ther 7:172-177.

Shah VP, Midha KK, Dighe S, McGilveray IJ, Skelly JP, Yacobi A, Layloff T, Viswanathan CT, Cook CE, McDowall RD, and et al. 1991. Analytical methods validation: bioavailability, bioequivalence and pharmacokinetic studies. Conference report. Eur J Drug Metab Pharmacokinet 16:249-255.

Smeyers-Verbeke J, Detaevernier MR, Denis L, and Massart DL. 1981. The determination of platinum in biological fluid by means of graphite furnace atomic absorption spectrometry. Clin Chim Acta 113:329-333.

Takahashi I, Maehara Y, Kusumoto H, Kohnoe S, and Sugimachi K. 1993. Heat enhances the cytotoxicity of cis-diamminedichloroplatinum(II) and its analogues cis-1,1-cyclobutanedicarboxylato(2R)-2-methyl-1,4- butanediammineplatinum(II) and cisdiammine(glycolato)platinum in vitro. Cancer Chemother Pharmacol 33:31-35.

Thiabaud G, Arambula JF, Siddik ZH, and Sessler JL. 2014. Photoinduced reduction of Pt(IV) 
442 within an anti-proliferative Pt(IV)-texaphyrin conjugate. Chemistry 20:8942-8947.

$443 \quad 10.1002 /$ chem.201403094

444 Tiwari G, and Tiwari R. 2010. Bioanalytical method validation: An updated review. Pharm

$445 \quad$ Methods 1:25-38. 10.4103/2229-4708.72226

446 Vouillamoz-Lorenz S, Bauer J, Lejeune F, and Decosterd LA. 2001. Validation of an AAS

447 method for the determination of platinum in biological fluids from patients receiving the oral

448 platinum derivative JM216. J Pharm Biomed Anal 25:465-475.

449 Westgard JO. 1981. Precision and accuracy: concepts and assessment by method evaluation testing. Crit Rev Clin Lab Sci 13:283-330. 10.3109/10408368109106450

451 Wills NK, Ramanujam VM, Chang J, Kalariya N, Lewis JR, Weng TX, and van Kuijk FJ. 2008.

452 Cadmium accumulation in the human retina: effects of age, gender, and cellular toxicity. Exp $453 \quad$ Eye Res 86:41-51. 10.1016/j.exer.2007.09.005

454 Ye J, Liu S, Tian M, Li W, Hu B, Zhou W, and Jia Q. 2014. Preparation and characterization of 455 magnetic nanoparticles for the on-line determination of gold, palladium, and platinum in mine samples based on flow injection micro-column preconcentration coupled with graphite furnace atomic absorption spectrometry. Talanta 118:231-237. 10.1016/j.talanta.2013.10.018

Yunos NM, Beale P, Yu JQ, and Huq F. 2011. Synergism from sequenced combinations of curcumin and epigallocatechin-3-gallate with cisplatin in the killing of human ovarian cancer cells. Anticancer Res 31:1131-1140.

Zheng YJ, Kang Y, Feng YZ, Zhang R, and Zhang WB. 2001. [Addition internal standard method in chromatographic quantitative analysis]. Se Pu 19:464-466. 
463 Zisowsky J, Koegel S, Leyers S, Devarakonda K, Kassack MU, Osmak M, and Jaehde U. 2007.

464 Relevance of drug uptake and efflux for cisplatin sensitivity of tumor cells. Biochem

465

Pharmacol 73:298-307. 10.1016/j.bcp.2006.10.003

466

467

468

469 
Figure 1 (on next page)

Comparison of different sample preparation methods.

A) Calibration curves of different sample preparation methods according to the absorbance of a series of platinum standard addition solutions ranging from $60 \mu \mathrm{g} / \mathrm{L}$ to $240 \mu \mathrm{g} / \mathrm{L}$. B) Platinum contents of A2780, HeLa, Hep $G_{2}$ cells processed using different methods. Student's t-test, $* \mathrm{P}<0.05, * * * \mathrm{P}<0.001, \# \mathrm{P}>0.05$. C) Platinum concentration of aliquots prepared using various oncentrations of nitric acid. 


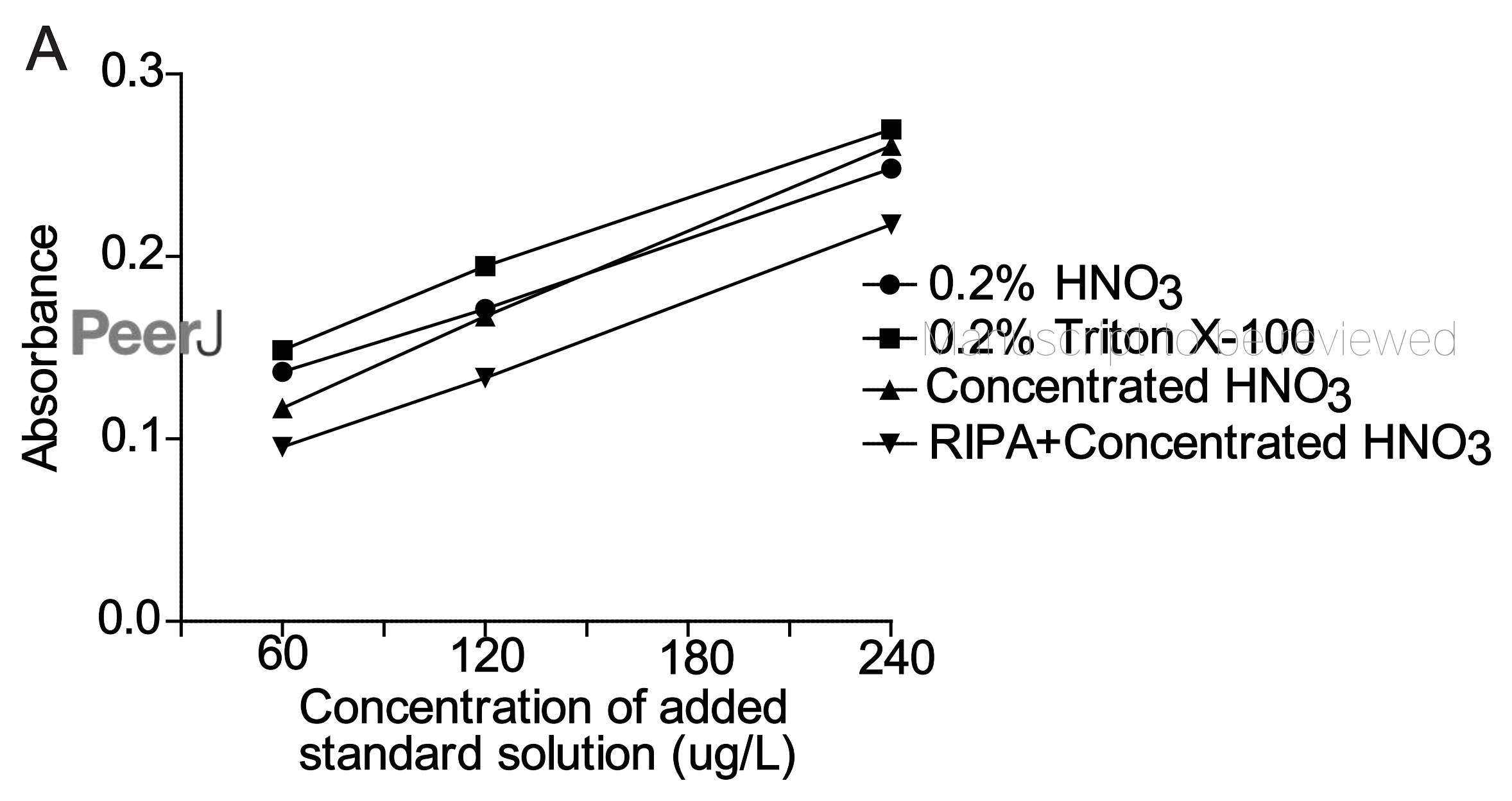

B

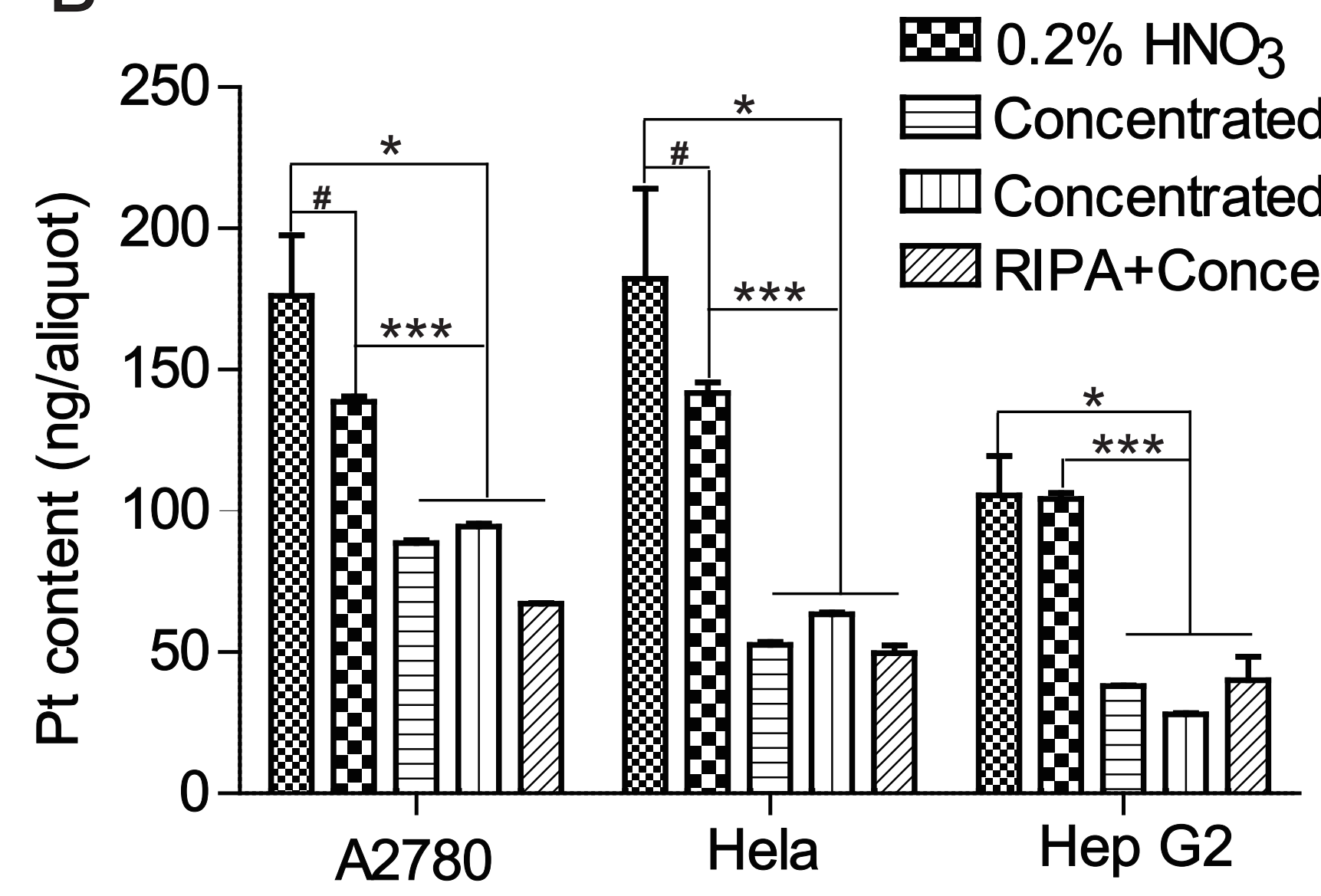

C

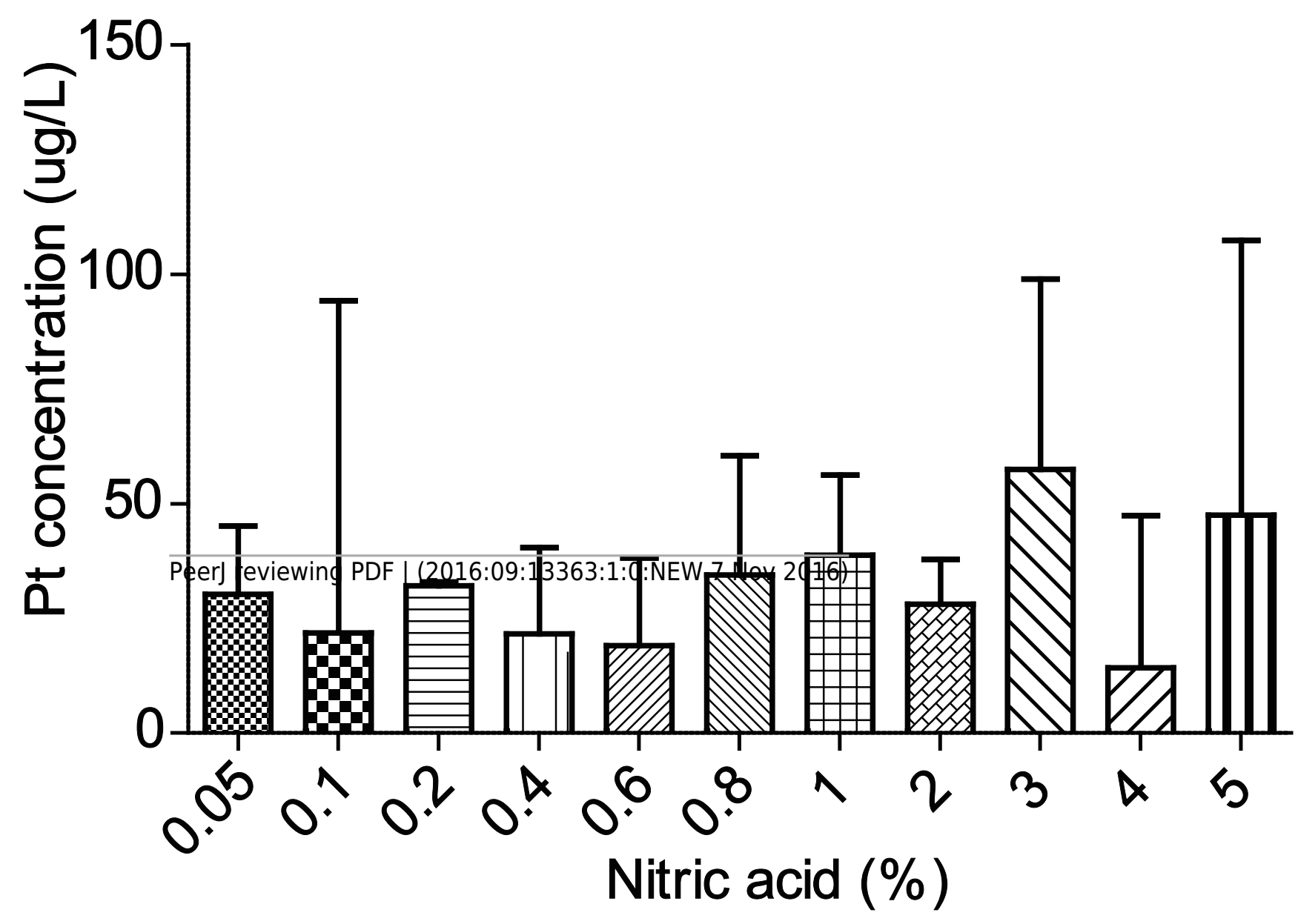




\section{Figure 2 (on next page)}

Practical application of the method.
A) The platinum concentration-time curves of $\mathrm{A} 2780$ and $\mathrm{CAOV}_{3}$ cells. B) Comparison of platinum accumulation in A2780 and its resistant variant A2780/CDDP after incubation with 20 uM cisplatin for 24 hours. Student's t-test, ${ }^{* *} \mathrm{P}<0.01$. 

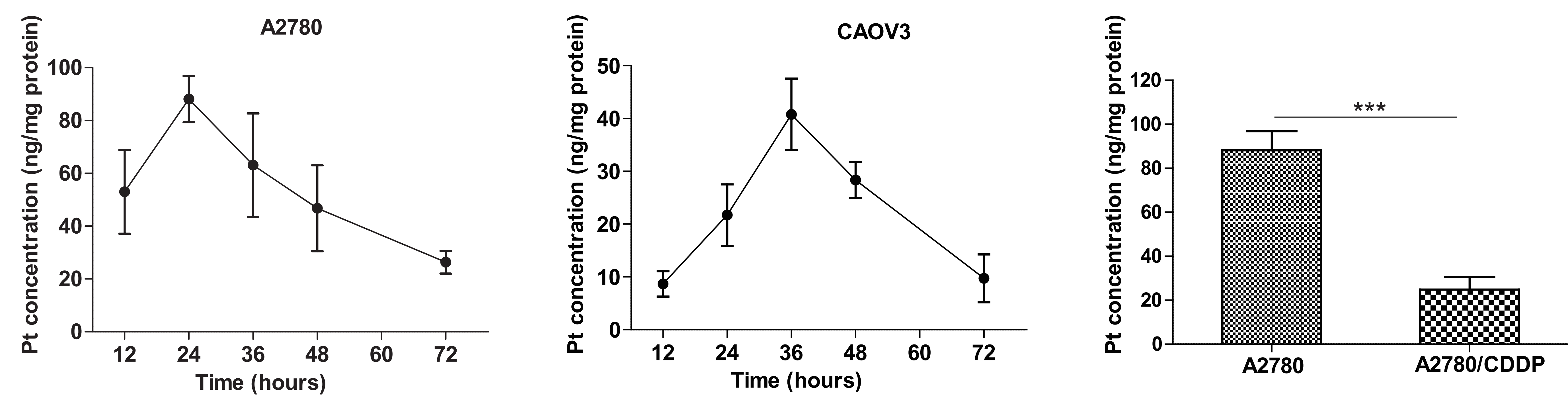


\section{Table 1 (on next page)}

Evaluation of accuracy in terms of recovery rate at different concentration levels. 
1 Table 1. Evaluation of accuracy in terms of recovery rate at different concentration levels.

\begin{tabular}{|c|c|c|c|c|c|c|c|c|c|c|}
\hline \multirow{2}{*}{$\begin{array}{l}\text { Cell } \\
\text { lines }\end{array}$} & \multirow{2}{*}{$\begin{array}{l}\text { Concentration } \\
\text { of sample } \\
(\mathrm{ug} / \mathrm{L})\end{array}$} & \multirow{2}{*}{$\begin{array}{l}\text { Added } \\
\text { standard } \\
\text { solution } \\
\text { (ug/L) }\end{array}$} & \multicolumn{6}{|c|}{ Number of the experiment } & \multirow{2}{*}{$\begin{array}{l}\text { Mean } \\
\text { (ug/L) }\end{array}$} & \multirow{2}{*}{$\begin{array}{l}\text { Average } \\
\text { recovery } \\
(\%)\end{array}$} \\
\hline & & & $\begin{array}{c}1 \\
(\mathrm{ug} / \mathrm{L})\end{array}$ & $\begin{array}{c}2 \\
\text { (ug/L) }\end{array}$ & $\begin{array}{c}3 \\
\text { (ug/L) }\end{array}$ & $\begin{array}{c}4 \\
\text { (ug/L) }\end{array}$ & $\begin{array}{c}5 \\
(\mathrm{ug} / \mathrm{L})\end{array}$ & $\begin{array}{c}6 \\
(\mathrm{ug} / \mathrm{L})\end{array}$ & & \\
\hline A2780 & 48.6 & 45.0 & 95.5 & 85.9 & 92.5 & 92.2 & 93.3 & 95.0 & 92.4 & 97.3 \\
\hline Hep G2 & 110.9 & 125.0 & 232.9 & 235.7 & 237.0 & 241.8 & 242.8 & 247.5 & 239.6 & 103.0 \\
\hline
\end{tabular}

2

3

4

5

6

7

8

9 
Table 2 (on next page)

Precision of the method evaluated as relative standard deviation at different concentration levels of $A 2780$ cells. 
1 Table 2. Precision of the method evaluated as relative standard deviation at different concentration levels of A2780 cells.

\begin{tabular}{ccccc}
\hline \multirow{2}{*}{ Number of the experiment } & \multicolumn{4}{c}{ Platinum concentration (ug/L) } \\
\cline { 2 - 5 } 1 & 42.8 & 80.4 & 117.1 & 186.3 \\
2 & 43.6 & 82.4 & 118.0 & 187.5 \\
3 & 43.9 & 82.5 & 119.9 & 190.6 \\
4 & 44.0 & 82.8 & 120.1 & 191.2 \\
5 & 45.8 & 83.4 & 120.4 & 191.8 \\
6 & 47.4 & 85.7 & 121.6 & 193.6 \\
Average & 44.6 & 82.9 & 119.5 & 190.2 \\
RSD * $(\%)$ & 3.8 & 2.1 & 1.4 & 1.5 \\
\hline
\end{tabular}

* Relative standard deviation 


\section{Table 3 (on next page)}

Influence of coexistent metals on platinum determination in Hep G2 cell samples. 
1 Table 3. Influence of coexistent metals on platinum determination in Hep G2 cell samples.

\begin{tabular}{|c|c|c|c|c|c|c|c|c|c|c|}
\hline \multirow[b]{2}{*}{ Metals } & \multirow{2}{*}{$\begin{array}{l}\text { Added } \\
\text { concentration } \\
\text { (ug/L) }\end{array}$} & \multirow{2}{*}{$\begin{array}{l}\text { Sample Pt* } \\
\text { concentration } \\
(\mathrm{ug} / \mathrm{L})\end{array}$} & \multicolumn{6}{|c|}{ Number of the experiment } & \multirow[b]{2}{*}{ Mean } & \multirow{2}{*}{$\begin{array}{l}\text { Average } \\
\text { recovery }(\%)\end{array}$} \\
\hline & & & $\begin{array}{c}1 \\
\text { (ug/L) }\end{array}$ & $\begin{array}{c}2 \\
\text { (ug/L) }\end{array}$ & $\begin{array}{c}3 \\
\text { (ug/L) }\end{array}$ & $\begin{array}{c}4 \\
\text { (ug/L) }\end{array}$ & $\begin{array}{c}5 \\
(\mathrm{ug} / \mathrm{L})\end{array}$ & $\begin{array}{c}6 \\
\text { (ug/L) }\end{array}$ & & \\
\hline $\mathrm{Ca}$ & 90.9 & 95.3 & 85.5 & 93.3 & 94.5 & 96.9 & 101.2 & 99.4 & 95.1 & 99.8 \\
\hline $\mathrm{Mg}$ & 90.9 & 95.3 & 104.0 & 96.5 & 100.8 & 94.0 & 93.5 & 99.3 & 98.0 & 102.9 \\
\hline $\mathrm{Fe}$ & 1.1 & 75.0 & 74.8 & 74.1 & 67.1 & 71.1 & 73.5 & 67.2 & 71.3 & 95.1 \\
\hline $\mathrm{Zn}$ & 12.2 & 102.2 & 111.5 & 95.4 & 92.6 & 103.2 & 95.3 & 98.1 & 99.4 & 97.2 \\
\hline $\mathrm{Cu}$ & 1.2 & 102.2 & 102.6 & 111.1 & 106.1 & 106.6 & 104.2 & 101.9 & 105.4 & 103.1 \\
\hline $\mathrm{Mn}$ & 1.2 & 102.2 & 96.0 & 95.8 & 108.9 & 107.5 & 107.6 & 107.6 & 103.9 & 101.7 \\
\hline $\mathrm{K}$ & 12.2 & 102.2 & 101.6 & 103.3 & 97.0 & 110.8 & 101.6 & 106.3 & 103.4 & 101.2 \\
\hline $\mathrm{Na}$ & 12.2 & 102.2 & 107.0 & 104.9 & 100.2 & 101.7 & 100.4 & 95.6 & 101.6 & 99.4 \\
\hline
\end{tabular}




\section{Table 4(on next page)}

Long-term storage stability of platinum concentration in cell samples. 
1 Table 4. Long-term storage stability of platinum concentration in cell samples.

\begin{tabular}{|c|c|c|c|c|c|c|c|c|c|c|c|c|}
\hline \multirow{5}{*}{$\begin{array}{l}\text { Cell } \\
\text { lines }\end{array}$} & \multirow{5}{*}{$\begin{array}{l}\text { Storage } \\
\text { conditions }\end{array}$} & \multirow{5}{*}{$\begin{array}{c}0 d \\
(\mathrm{ug} / \mathrm{L})\end{array}$} & \multicolumn{10}{|c|}{ Storage time } \\
\hline & & & \multicolumn{2}{|c|}{$7 d$} & \multicolumn{2}{|c|}{$14 d$} & \multicolumn{2}{|c|}{$21 d$} & \multicolumn{2}{|c|}{$35 \mathrm{~d}$} & \multicolumn{2}{|c|}{$60 d$} \\
\hline & & & & Average & & Average & & Average & & Average & & Average \\
\hline & & & $\mathrm{C}^{*}$ & recovery & $\mathrm{C}^{*}$ & recovery & $C^{*}$ & recovery & $\mathrm{C}^{*}$ & recovery & $C^{*}$ & recovery \\
\hline & & & (ug/L) & $(\%)$ & (ug/L) & $(\%)$ & (ug/L) & $(\%)$ & (ug/L) & $(\%)$ & (ug/L) & $(\%)$ \\
\hline \multirow[t]{2}{*}{ A2780 } & $-20^{\circ} \mathrm{C}$ & 110.9 & 112.7 & 101.6 & 126.3 & 113.9 & 124.6 & 112.4 & 116.2 & 104.8 & 96.4 & 87.0 \\
\hline & $-80^{\circ} \mathrm{C}$ & 110.9 & 100.7 & 90.8 & 111.9 & 100.9 & 126.2 & 113.8 & 121.7 & 109.8 & 98.0 & 88.4 \\
\hline \multirow[t]{2}{*}{ HeLa } & $-20^{\circ} \mathrm{C}$ & 109.4 & 113.6 & 103.8 & 104.7 & 95.7 & 113.6 & 103.9 & 96.8 & 88.5 & 112.3 & 102.7 \\
\hline & $-80^{\circ} \mathrm{C}$ & 109.4 & 111.2 & 101.6 & 121.8 & 111.3 & 123.6 & 113.0 & 108.7 & 99.4 & 112.6 & 103.0 \\
\hline \multirow[t]{2}{*}{ Hep G2 } & $-20^{\circ} \mathrm{C}$ & 113.4 & 113.7 & 100.3 & 113.9 & 100.4 & 117.2 & 103.3 & 112.1 & 98.9 & 101.9 & 89.9 \\
\hline & $-80^{\circ} \mathrm{C}$ & 113.4 & 117.0 & 103.1 & 102.3 & 90.2 & 111.8 & 98.6 & 107.6 & 94.9 & 122.2 & 107.8 \\
\hline
\end{tabular}


Table 5 (on next page)

Stability of platinum concentration during cell sample processing. 
Table 5. Stability of platinum concentration during cell sample processing.

\begin{tabular}{|c|c|c|c|c|c|c|c|}
\hline \multirow{4}{*}{$\begin{array}{l}\text { Cell } \\
\text { lines }\end{array}$} & \multirow{4}{*}{$\begin{array}{c}\text { Starting point } \\
\mathrm{C}^{*} \\
(\mathrm{ug} / \mathrm{L})\end{array}$} & \multirow{2}{*}{\multicolumn{2}{|c|}{$\begin{array}{c}\text { Unsealed } \\
3 \mathrm{~h}\end{array}$}} & \multicolumn{4}{|c|}{ Sealed } \\
\hline & & & & \multicolumn{2}{|r|}{$24 \mathrm{~h}$} & \multicolumn{2}{|r|}{$48 h$} \\
\hline & & $\mathrm{C}^{*}$ & Average & $\mathrm{C}^{*}$ & Average & $\mathrm{C}^{*}$ & Average \\
\hline & & (ug/L) & recovery $(\%)$ & (ug/L) & recovery $(\%)$ & (ug/L) & recovery $(\%)$ \\
\hline Hep G2 & 117.0 & 110.8 & 94.7 & 108.6 & 92.8 & 111.1 & 95.0 \\
\hline A 2780 & 98.0 & 91.6 & 93.5 & 104.4 & 106.5 & 102.4 & 104.5 \\
\hline A2780 & 40.0 & 44.5 & 111.2 & 43.3 & 108.2 & 42.2 & 105.5 \\
\hline
\end{tabular}

